Portland State University

PDXScholar

$11-21-2019$

\title{
The Death of Physical Media: The Dangers of Streaming and the End of the Home Library
}

Amelia Eichler

Portland State University

Follow this and additional works at: https://pdxscholar.library.pdx.edu/honorstheses

Part of the Other Film and Media Studies Commons Let us know how access to this document benefits you.

\section{Recommended Citation}

Eichler, Amelia, "The Death of Physical Media: The Dangers of Streaming and the End of the Home Library" (2019). University Honors Theses. Paper 803.

https://doi.org/10.15760/honors.821

This Thesis is brought to you for free and open access. It has been accepted for inclusion in University Honors Theses by an authorized administrator of PDXScholar. Please contact us if we can make this document more accessible: pdxscholar@pdx.edu. 
The Death of Physical Media: The Dangers of Streaming and the End of the Home Library By

\title{
Amelia Eichler
}

An undergraduate honors thesis submitted in partial fulfillment of the requirements for the degree of

\author{
Bachelor of Arts \\ in \\ University Honors \\ and
}

Film

Thesis Adviser

Mark Berrettini

Portland State University 
As technology has changed throughout the 20th and 21 st century, the way in which movies are viewed within the home has changed dramatically. The home library has taken on many different forms throughout history. The German philosopher, Walter Benjamin, wrote about this magical relationship between collector and object in his essay "Unpacking My Library". To him, ownership of an object allowed the collector to unlock memories of its past and "renew the old world", while also creating new memories with that object (Klinger 65). For example, beginning in the 1930s, a company called Castle Films released over three-hundred Hollywood films on 8mm, an amateur film gauge. Enthusiasts were able to create their own libraries by ordering the films through Castle's mail service (MacGillivray 17). Film hobbyists' desire for an intimate relationship with their favorite films extended into a desire to collect them and build their own library. Additionally, this allowed people to become curators of their own collection as they could engage with their collection in whatever way they saw fit. Currently, the acquisition of film in the physical form is endangered. The collector that Benjamin spoke of is becoming an obsolete figure. The relationship between collector and object is also at risk, thanks to digital streaming becoming the new way to consume films inside the home. Streaming has become the most convenient way to consume films and television shows for most consumers.

This thesis will explore different types of physical media that found their place within the home library, such as pre-cinematic formats, film gauges, VHS, and DVD/Blu-ray. Then, I will explore how these different technologies were collected into the home library and why they were important. Lastly, I will discuss why some of these technologies no longer exist, and distinguish why streaming is different from earlier forms of home media and why this technology is detrimental to the home library. 
Long before the days of film collection, consumers were able to collect forms of early media through pre-cinematic, non-celluloid devices. Although they weren't considered film libraries, consumers were able to begin to collect various physical media that before would have not been possible. The next media that arrived in the home was VHS. Scholars such as Barbara Klinger and Joshua Greenberg discuss how the movie library didn't reach "democratization" until the arrival of VCR and VHS, but even long before cinema, it was possible for consumers to build libraries that they were in control of. Klinger states: "As movie ownership has become more pervasively defined by VHS and DVD, it has become dramatically democratized" (57). Advances in technology allowed for more accessibility. The average consumer would be able to operate a $8 \mathrm{~mm}$ toy projector, VCR, or Laserdisc player. Creating a film library wasn't realistically affordable until the arrival of Castle's $8 \mathrm{~mm}$ films and VHS tapes. However, the more accessible media became, the more the studios became concerned about the freedom consumers had once they owned the product. In order to understand this recurring conflict between studio \& copyright and the consumer, it's important to look at the beginning of the home library.

Ben Singer has noted that the motion picture made its appearance in the home within months of its first public appearance in the 1890s (38). Singer stated that the appearance of films in American homes took place in 1897 after Edison's Kinetoscope viewer made its first public appearance. A company called the American Kinetoscope Parlor created a similar visual experience by making a smaller viewer for the home (Singer 38). However, other scholars note the appearance of projection onto a screen as early as the 1600 s. In Karl D. D. Willis' article $A$ Pre-History of Handheld Projector-Based Interaction, one of the earliest uses of a handheld 
projector started with a device called the magic lantern: "Light emitted from a candle or oil lamp would be collected by a concave mirror and projected on through a painted slide. Light passing through the lantern's lens would project an enlarged version of the slide image onto a screen" (5). Many of these magic lantern "shows" were often confined for home amusement. It wasn't until the 1760s that the lantern was used for shows outside the home (DeadMediaArchive). There were many other types of pre-cinema projection and optical toys that came along after the magic lantern was used in the home: Thaumatrope (1824), Fantascope (1831), Zoetrope (1834), and the Phasmatrope (1870). The Thaumatrope was a Victorian toy that consisted of a circular disc with two strings and two images on each side. When the strings were twisted, the speed of motion tricked the eye of the operator because the images switched faster than a tenth of a second. Psychologists would later call this phenomena "persistence of vision," and it would be applied to the experience of viewing film frames projected in rapid sequence (Glass). Another toy that relied on persistence of vision was the Phenakistoscope (1833). They were animated discs that were attached to a handle and when spun created animated images (Huhtamo 50). The discs were sold in books that contained a few different discs by various distributors. Laying out all the discs on tabletops within the home depicted images with picturesque landscapes (Huhtamo 51). The Zoetrope, a cylinder-shaped device, was one of the first devices to give off the illusion of motion through the movement of static images at a rapid pace. It functioned as so: As the cylinder spins, the user looks through the slits at the pictures across. The scanning of the slits keeps the pictures from simply blurring together, and the user sees a rapid succession of images, producing the illusion of motion" (Zoetrope). These are all considered pre-cinematic devices because they were machines and toys that did not rely on celluloid to actually capture movement. These early 
pre-cinematic toys influenced inventors to find a way to create actual moving images. The home library that contained moving images came into fruition during these formative years. Before celluloid, people could collect discs, slides, and paper rolls (Huhtamo 368). The use of persistence of vision established by these pre-cinematic technologies carried over to the projection of actual filmic images.

The timeline of who was the first to capture moving images on celluloid is a little tricky as many different devices were pumped out in quick succession during the 1800s. Scholars look back at this era (1845-1890) as the pre-cinema era (Faubel 260). French scientist Etienne-Jules Marey and photographer Eadweard Muybridge both used chronotography to capture movement. This was a photographic technique that captured a succession of images on a sheet. In the 1870s, Marey experimented with chronotography in order to capture movement that could not be seen by the human eye (Faden 96). Around the same time, Muybridge was engaged in capturing motion through photography and did so successfully with his famous Horse in Motion "film" (Faubel 260). Before celluloid film loops were being ran through projectors, these chronotographers created loops using photographs that succeeded each other. These loops were often run through both the zoetrope as well as the zoopraxiscope. The zoopraxiscope, designed by Muybridge himself, was used to project discs that contained drawings or photographs in quick succession (Hill \& Herbert 100).

Understanding how these loops, slides, and drawings were collected and placed within the home is rather difficult to analyze as there aren't many resources on their home consumption. Sources which detail how consumers within the 19th century were targeted are few and far between. Consumers could collect these optical toys by ordering from catalogues, the pieces then 
being delivered through the mail. For example, a catalogue called "Instructive Optical Toys" sold discs for the magic lantern that had illustrations of famous stories on them (Gebrüder). It's assumed that people could collect the zoopraxiscope discs that contained various sketches and drawings similar to the Zoetrope, various papers containing different sketches were most likely ordered through catalogues and trade papers. In terms of information on marketing and pre-cinematic consumer libraries, it is sporadic and difficult to create a unified timeline. Early victorian optical mechanisms were often advertised towards children as "optical toys". These toys made their debut in the 1830 s; however, primary source material containing ads for these could not be located. These early optical toys included the Phenakitiscope (1831), the Zoetrope (hit mass market in 1860), and the Praxinoscope. Scholars Leo Douglas and Graham Enticknap also noted the Zoetrope as being one of the first to be mass-marketed with the paper-strips for the device being priced for less than a newspaper (6-7). The marketing for the Magic Lantern was a step above the Zoetrope because it projected actual photographs on glass slides. Although they were first grouped with scientific instruments in the 19th century, the technology eventually made its way to the American toy market, with advertisements reaching newspapers in the $1880 \mathrm{~s}$ (Douglas \& Enticknap 7-9). Illustrations of the Magic Lantern within the home showed parents presenting shows for their children (Douglas \& Enticknap 5). From a contemporary perspective, many of these optical toys could presumably double as fixtures among the house. Similarly to that of the physical media that arrived in the late 20th century, carrying-cases that allowed users to carry their slides were often sold with the Magic Lantern. Early slides often included pictures of paintings and natural history (Douglas \& Eticknap 5). The purchasing of additional slides could be done through catalogues, manuels, or trade magazines that were published in the 19th 
and 20th century. Collectors could also purchase different lenses, screens, and carrying cases for the screens. They could learn about these accessories through books and catalogues such as Magic Lanterns Stereopticons Projection Apparatus: Lantern Slides and Accessories (McIntosh Stereopticon Company). One section within a manual for the model of a Magic Lantern provides collectors with a guide on how to organize their slide case so that it is easier to access their library (McIntosh Stereopticon Company). From looking at primary source material, it's clear that these pre-cinematic optical toys were meant to be used within the home and they direct consumers on how to set-up these devices, a practice which continued until the 20th century. Although cinematic devices came into fruition in the 1890 s, I've found ads and manuals for the Magic Lantern that were distributed until the 1920s (Wells 23-24).

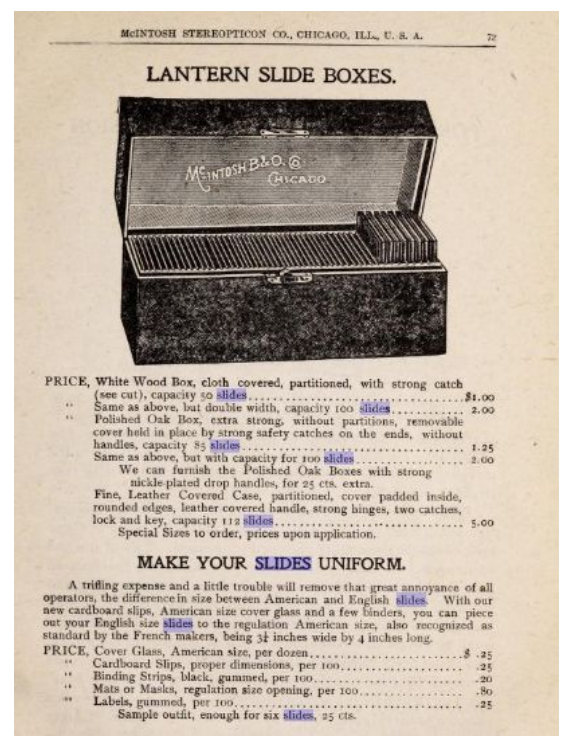

Image: Advertisement for lantern slide case (McIntosh Stereopticon Company 72) 
According to Wells, the Magic Lantern and other optical toys floundered after World War I (1920 and 1921) in favor of more mechanical toys (23-24). These optical toys were important because they started the consumer relationship with the home library that served as a model for other technologies. The library had already begun to take shape within the home allowing consumers to collect and organize glass slides for their magic lanterns. Mechanical technology that could run celluloid would use a similar distribution-by-mail model that the lantern slides used. The portability of the Magic Lantern served as a model for many of the projectors that designed within the next decade (Rogers 148). They were already shaping up libraries that allowed them to have access to a number of different subjects. By this time the Magic Lantern appeared outdated since consumers were able to project and view actual celluloid within the home.

Thomas Edison always believed that film would find its permanence within the home. He wanted to create a mechanism that could bring moving images into the home just as the phonograph had done years before (Wasson 6). He stated: "I am experimenting upon an instrument which does for the eye what the phonograph does for the ear, which is the recording and reproduction of things in motion ...." (LOC). After being influenced by the godfather of pre-cinema mechanisms (Muybridge), Edison decided to create a camera that could record movement and sound on film rather than paper. His assistant William Dickson was actually responsible for creating the camera that was now able to record actual movement. Later John Carbutt worked with Dickson to create emulsion-based celluloid film sheets to capture images onto. Once the camera was created, Dickson began to create a prototype for a viewer that could be used to project the developed film. In 1891, the Kinetoscope viewer was shown at a 
convention in which $18 \mathrm{~mm}$ film was viewed through a peephole. Not long after its completion in 1892 did a smaller version of the Kinetoscope arrive in the home (LOC). The standard Kinetoscope was a viewer that showed $35 \mathrm{~mm}$ film that was threaded on rollers, resulting in an endless film loop. A person looked into a viewer and watched a succession of images (LOC). "As each frame passed under the lens, the shutter permitted a flash of light so brief that the frame appeared to be frozen. This rapid series of apparently still frames appeared, thanks to the persistence of vision phenomenon, as a moving image" (Robinson 34). There were many different machines with non-standard and standard gauges that entered the home library. Ben Singer noted that the first American projector made for the home was in 1897 with a projector that resembled the Kinetoscope, but was much smaller and cheaper in design (38). It's important to note that machinery is also part of the home library. This design by the American Parlor Kinetoscope Co. allowed for the first movie library to find itself within the home. The manufacturer of this device provided consumers with film loops also known as "picture belts", that had a cost range between $\$ 3$ or $\$ 6$. In the catalogue found by Singer, there were eleven subjects that could be purchased and they were often the same loops that were viewed in public Kinetoscope parlors (38). This was one of the first times that commercial films were available to the consumer after they completed their run in venues. One thing that isn't clear when it comes to acquiring early film loops is whether or not they were rented or purchased by consumers from the manufacturers. There is no way to tell whether or not this early device or these films were successful in the home market. With the arrival of the Kinetoscope and the ability for consumers to acquire picture belts, this is the time in which the home movie library was established and users were in control of viewing motion picture film. 
Various designs in machinery were developed as a way to find a more economical and consumer-friendly projector that could penetrate the market. At the same time, companies were trying to find both an affordable film stock and cameras for amateur filmmakers to purchase (Kattelle 47). Nitrate was too flammable and unsafe for people to be using within the home. The original purpose of some of these gauges were so that businesses could tap into the amateur filmmaking market. Many cameras doubled as projectors, which was more viable for consumers. One of the first of these dual machines was designed by Birt Acres in May of 1899 with other designs and gauges being marketed years later (Horak). The machine was called the Birtac and is regarded as the first machine that was made for the amateur filmmaker. It employed $17.5 \mathrm{~mm}$ film by splitting $35 \mathrm{~mm}$ in the middle (Science Museum Group Collection). Ben Singer noted some other home movie projectors that made their way into the home and with that, the ability to acquire physical films in different gauges for the family: The Vitak $(1902,11 \mathrm{~mm})$, The Homograph (1911), and The Ikonograph (1904-1906, 17.3mm). These were all projectors that could project celluloid onto a screen. Since there wasn't a standard amateur/home library gauge, many of these projectors had different gauges. One thing they had in common was that they all used flammable nitrate stock. The Ikonograph was a projector that used $17.3 \mathrm{~mm}$ with the perforation in the middle of each frame. It was also the first projector to be able to run film backwards (Kattelle 47). Many of these machines were given to consumers with a certain amount of free film loops that they, presumably, were able to keep (Singer 39). The Homograph manufacturers boasted that they had an unlimited film library that consumers could purchase from, each film allowing for ten seconds of viewing:

“"We carry in stock an unlimited supply of film. The subjects embrace almost every 
topic imaginable. Dramas, heavy and light; Comedies, Industrial and Religions Pictures; Rough riding, Wild West, Boxing, Automobile and Sporting Pictures of all kinds. These pictures are manufactured by Pathe, Freres, Vitagraph, Biograph, Edison, Bison, Imp and the numerous other manufacturers"' (Singer 40).

However it seems that there wasn't a substantiated distribution market for home consumers to purchase or rent films to add to their library. Media scholar Barbara Klinger noted that there were brick-and-mortar outlets being setup so that consumers could purchase and or rent titles for their libraries (6). However, the search continued for the right gauge namely due to the fact that these formats were made up of flammable nitrate film stock and many times the film would tear from being run so frequently (Horak).

The answer for a stronger, safer film gauge for more users was on the horizon with the arrival of the Pathescope in 1913, designed by French film company Pathe. Around the same time, the arrival of Edison's Home Projecting Kinetoscope in Europe allowed distribution networks to become standardized so that consumers were able to purchase films for rent. One of the big reasons for this was that the films were made of safety stock (Schnieder 356). Owners of the projector would hand crank the film forward. Media scholar Alan Kattelle described how the project works: "The image rows were arranged in head-to-tail fashion; by alternately cranking the projector forward, side-shifting, and cranking in reverse, all three rows were projected in their proper sequence" (48). $28 \mathrm{~mm}$ film was able to be purchased through the mail for a yearly subscription or by borrowing titles weekly (Singer 44-46). The Edison distribution chain allowed consumers to purchase $22 \mathrm{~mm}$ films through distribution-by-mail instead of by local libraries. Pre-dating the system used by DVD Netflix, both the Edison and Pathe services allowed 
consumers to rent or purchase films through the mail, so that people didn't have to leave their houses (Luckett 21). Consumers were able to keep a film until they decided they no longer felt it was of interest and they could return it back for other titles. The Edison distribution system seemed to allow consumers to create a film library since there was no requirement to return the titles unless they grew tired of them. People were able to have access to those titles and only had to pay for what they wanted to experience. Films for the Edison catalogue were divided into different prices depending on content, length, and the type of lens or light needed to project it. Unfortunately, the films were not feasible to print or mail out and the system went defunct in 1914 (Singer 44-46).
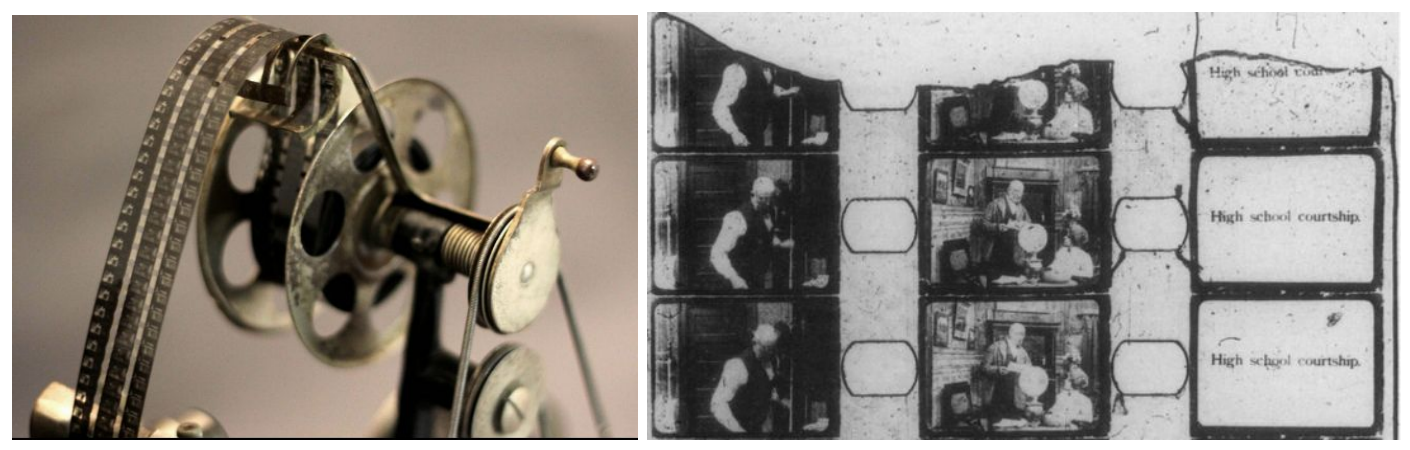

Figure 2: Edison Kinetophone loaded with 22mm film (USC). Figure 3: Frames from a $22 \mathrm{~mm}$ film (Singer 47)

In the end, Pathe came up on top by creating, at the time, the most successful amateur gauge for the home library--9.5 $\mathrm{mm}$. The $9.5 \mathrm{~mm}$ gauge was as big as $16 \mathrm{~mm}$, in terms of stock, which wouldn't reach the market for another decade, with the difference being that the perforation was in the middle of each frame (Horak). Consumers could order commercial features, spanning many different genres including dramas, cartoons, educational films, and so on. Consumers needed to be subscribed to the order-by-mail service in order to purchase these 
titles. Price depended on reel size and whether the film was silent or sound (Pathescope Co. of America). Pathe sold films to home consumers well into the forties. However, the $9.5 \mathrm{~mm}$ gauge didn't take off in America and mainly remained popular in Europe (Horak). 9.5mm didn't have the best image quality because the middle perforation between each frame caused stripes to show up across the screen. Additionally, due the film stock that was used for $9.5 \mathrm{~mm}$ was flammable and the film was more apt to get damaged this way when it was going through the projector (Horak).

These earlier gauges were extremely important in creating the home library. These inventions allowed consumers to watch actual celluloid for the first time within the comfort of their own homes. The large amount of films available for purchase allowed people to become collectors. They were able to curate films within their home library and project films for their family members or neighbors. Rewatchability was possible for the renter or purchaser of these various gauges because they could actually have physical access to them. This home library only continued to grow as many more handheld projectors were able to be purchased by consumers. Marketers needed to find a standard gauge that was safe enough for amateur filmmakers and film collectors to use (Horak).

In the year 1923, distribution and rental services for the home movie library began to become more well-defined. Stock was less flammable and there was more equipment available to support this gauge. The projector was more affordable and there were accessories that could be purchased to go along with the machine. Advertisements of these accessories enticed consumers to create their very own home theater. These accessories included: cabinets, stands, translucent screens, and carts (Rogers 148-149). The gauge propelled its way into the market because it was 
more affordable in distribution and exhibition. The cost to print and ship films was considerably cheaper than previous formats. $16 \mathrm{~mm}$ already had many technological advantages over the other non-standard formats that plagued the home library decades before. Film scholar Haidee Wasson noted 1923 as being a big breakthrough for film flourishing within the home due to the arrival of $16 \mathrm{~mm}$ film (1). Unlike other film formats, Eastman Kodak decided that $10 \mathrm{~mm} \times 7.5 \mathrm{~mm}$ was the minimum frame size in order to have good image quality. $16 \mathrm{~mm}$ had perforations on both sides of the image, which allowed for less damage to the film image (Horak). Early acetate film stock was used for these $16 \mathrm{~mm}$ prints, making the it safe for the home (Theakston). The standard gauge of $35 \mathrm{~mm}$ that was used for commercial exhibition was not safe enough to be marketed for the home since flammable nitrate film stock was used; the industry had yet to introduce safer stocks such as acetate or polyester until a decade later (Kattelle 49). The home library really seemed to come into fruition when Eastman Kodak announced in 1927 that they would be selling reduction prints of both theatrical and nontheatrical films to consumers (Schnieder 353). In 1932, once sound was inscribed on film stock, $16 \mathrm{~mm}$ had the ability to have two different soundtracks for film--optical and magnetic sound (Horak). The next several years were full of rampant advertising towards $16 \mathrm{~mm}$. Film exchanges also began to become more common and consumers were greeted with more titles than ever before.

As the expansion of home movie libraries became vast with titles, equipment also became more available, allowing home consumers the ability to create a movie library and an equipment archive. Screens, projectors, and cameras were being marketed in 1923 to coincide with the arrival of the 16mm gauge (Wasson 18), and this coincided with the growing idea of leisure within the home when consumers were being beckoned by marketers to begin collecting records, 
books, and radios. Some of these exchanges included: Bell and Howell's Film Library, Kodak's Kodascope Library, and Pathe's Pathescope Library (Wasson 7). One of the first catalogues to sell prints to film enthusiasts was Universal's "Show-At-Home" film exchange, which had a plethora of commercial titles available. A consumer was able to go to a local camera store where they could buy the films, which were sold for \$20 a reel (roughly \$307 in 2019) (Theakston). The camera stores would purchase films from a catalogue provided by Universal. Ads emphasized the ability for people to now be able to watch their favorite films within the home. Projectors were also more mobile and could be easily carried around in cases that were either built-in or bought seperately (Wasson 7). Kodak’s Kodascope Library required a one-time membership fee of twenty-five dollars in order to use and receive exclusive benefits (Kodascope Library 82). Upon filling out the membership card Kodak stated that, upon signing, a new member agreed:

"That I will observe the rules of the Kodascope Library, as outlined in the catalogue, that I will return my films promptly, that I will not lend, borrow, or exchange Library Films with others and that I will be responsible for serious injury to Library films with others and that I will be responsible for serious injury to Library Films while they are in my possession" (Kodascope Library 82).

Purchasing films were more expensive than renting, making it more popular for subscribers to rent titles. Still, $16 \mathrm{~mm}$ was a big breakthrough in the movie library because it became the standard gauge for the home movie industry. $16 \mathrm{~mm}$ film continued to flourish in the $1940 \mathrm{~s}$ and 50's. Standardization allowed for more technology and films to be available for consumers to purchase for their homes. Not only was the film itself more viable, but the equipment that was 
sold to families were more "user-friendly" than earlier projector models. Illustrations showed that families could now gather around the living room to watch their favorite films together, which was not very feasible before. People's living rooms had access to entertainment and education through film like they never had before. Some projectors were designed to look like suitcases so they could be put away with ease without taking up space in the home. Film exchanges became more prevalent, creating the rental service model that brick-and-mortar video rental stores would borrow from. At that point in time $16 \mathrm{~mm}$ had a superior image quality in comparison to earlier gauges. It was now safe for people to collect and show films in the home thanks to a safety stock. Accessories were sold along with the projectors in order to create a complete viewing experience. People were given the ability to choose whether they wanted to rent or purchase titles, allowing them to pay for the experience they wanted (Wasson 15).


Image: Ad for a film from the Kodascope Library (Fiola) 
$16 \mathrm{~mm}$ film collecting lasted well into the $1980 \mathrm{~s}$, but lost out to videotapes, which at the time were thought to have superior image quality (Horak). Until then, $16 \mathrm{~mm}$ had to compete with other smaller gauge formats such as $8 \mathrm{~mm}$ and Super8mm.

Additionally, the arrival of the smaller $8 \mathrm{~mm}$ film gauge in the 1930s also resulted in many film titles to be available through the studios (Wasson 12). A company named Castle Films also made purchasing films more affordable as opposed to the Kodascope and Show-At-Home catalogues (Theakston). Also, a new emulsion allowed for a high quality image even though the frame was half the size of $16 \mathrm{~mm}$. Castle Films specialized in $16 \mathrm{~mm}$ and $8 \mathrm{~mm}$ films, silent or sound, for the home viewer. For those who owned projectors without sound, Castle Films came with title cards that explained the dialogue. In 1937, the company sold one-reel subjects that replicated the movie-going experience at the time. Collectors could watch the same newsreels, sports films, travelogues, and silent "old" films that they would see in theaters (MacGillivray 16). If $16 \mathrm{~mm}$ was easy to use, $8 \mathrm{~mm}$ was even easier. They made small three-minute reels for those with toy projectors and for those who were on a budget (MacGillivray 4). Unlike the $16 \mathrm{~mm}$ film catalogues, Castle films fans were encouraged to purchase these films because you could choose to curate your own movie shows at home. The film catalogue also gave tips to collectors of home libraries on how to take care of their films and keep their projectors clean (MacGillivray 17).

Interestingly Castle Films was the first to promote the idea that owning these films meant you could watch them anytime you want. An ad for their company stated: "Then you can always select the show you want when you want it" (MacGillivray 11). In the 1940s, Hollywood caught onto the phenomena of licensing their films to those with movie libraries. For those in small 
towns, this was a way to access films without having to drive to the nearest city to find a theater. In 1945, Universal opened their own library that allowed consumers to rent $16 \mathrm{~mm}$ films from them. One of the biggest breakthroughs for home movie distribution was when Universal created a subsidiary called United World Films that specialized in distributing non-theatrical formats to consumers. They also merged with Castle Films to produce shortened versions of feature-length films that Universal had produced years before (MacGillivray 8). These were convenient for home users who may have not had the time to watch a full-length feature, but still wanted movie going to be apart of their daily routine. Films were available for purchase through mail catalogues, department stores, and even sporting goods stores (MacGillivray 10). In the seventies, Castle Films changed its name Universal 8 and began releasing feature length films rather than "highlight reels", which were eight minutes long. This enterprise lasted until the 1980s when videotape took over the home libraries (MacGillivray 18).

Unlike collecting 16mm, Castle films were cheaper and were aimed more at the every-day hobbyist. Castle was one of the first to promote the idea that people could be in charge of their own film libraries. Those who were dedicated, "underground" film collectors with money often collected $16 \mathrm{~mm}$ and $35 \mathrm{~mm}$. Castle Films were a non-illegal, in expensive way to purchase their favorite films. The affordability of these films also allowed consumers to be able to purchase more films rather than only rent titles.

Super $8 \mathrm{~mm}$ was essentially the same as regular $8 \mathrm{~mm}$. The format was introduced in 1965 by Kodak. Essentially the frames were enlarged by $50 \%$ so that the image covered more of the frame than $8 \mathrm{~mm}$ did (Horak). Castle Films advertised these the same as they did with regular $8 \mathrm{~mm}$. They were short versions of commercial films. The drawback of this format is that there 
weren't many feature-length films released, they were typically all condensed films. Those who wanted to collect films on a budget had to settle for an edited version. Celluloid within the home movie library continued well into the seventies and still has a place in contemporary libraries (Horak). Decades later this control would come into question as new formats arrived on the scene and studios wanted to make money over the purchase of their films. The following decades resulted in very large changes in the acquisition of films for the cinema lover's library.

With the help of new film stocks such as acetate and polyester, $35 \mathrm{~mm}$ film was safer to project and keep within the home (PSAP). Due to the fact that libraries contain movies that are copyrighted by studios, copyright issues and the home library are often intertwined. Collecting $16 \mathrm{~mm}$ and $8 \mathrm{~mm}$ prints from catalogues was the non-illegal way to collect films for the home library. This type of film collecting was for the more elitist, dedicated film collector who wanted to have commercial, full-length, high-quality films in their library. This activity was not exclusive to $35 \mathrm{~mm}$ as many film collectors also illegally obtained $16 \mathrm{~mm}$ prints of film and television shows that were not available through catalogues (Bordwell).

Somewhere along the line, the studios who rented out these prints may have lost track of the various films they rented out to theaters. Then, collectors began to create catalogues for other collectors to buy commercial $35 \mathrm{~mm}$ and $16 \mathrm{~mm}$ films. It was during this time that the studios no longer had control over the home movie library and collectors were creating their own networks to obtain $35 \mathrm{~mm}$ prints and $16 \mathrm{~mm}$--illegally. Many of these collectors were extreme cinema enthusiasts. An interview with collector Woody Wise provides us some insight into how these collectors obtained prints:

“"When a movie breaks back then [in the 1960s], they put it in like a hundred theaters,"” 
Wise explained. '“And, of course, that's film. That's 100 films. After two or three weeks, they only need like 20 and [the movie studios] pay tax on every print that's in the room... so they have to junk 80 prints - they have to throw them away. So you can kind of guess the story there, when I find out they're throwing these things away....” (Novak). Wise would pay the salvage workers a measly $\$ 15$ to $\$ 20$ for a print that he would later resell. Since each print contained copyright material that was copyrighted by the studios, they claimed that the films were illegally obtained and sold. However, Wise claims he did nothing wrong since the prints were being thrown out by the studios. But the collectors did not have a receipt to prove they purchased these from the studios because they simply didn't (Novak). If $8 \mathrm{~mm}$ Castle Films were the cheapest way to build a film collection, $35 \mathrm{~mm}$ was the exact opposite. The equipment took up a lot of room and the most passionate collector would typically renovate their home to create an immaculate screening room (Bordwell). Another way film collectors would gather prints for their libraries were from $16 \mathrm{~mm}$ resell catalogues.

Two film collectors, Dennis Bartok and Jeff Joseph, document these collectors and their libraries through a book titled $A$ Thousand Cuts: The Bizarre Underground World of Collectors and Dealers Who Saved the Movies. Studios became aware of the network of collectors after they busted actor Roddy McDowell for his film collection (Bartok \& Joseph 13-14). This resulted in the "film busts" of 1974-1975, which caused many film collectors to be raided by the FBI, local law enforcement, and the associates working for the MPAA (Bartok \& Joseph 14). Bartok noted that the court case of Bobbs-Merrill Co. v. Straus (1908) to be the case that allowed collectors to resell any item that they no longer wanted to read, listen to, and so on. The owner of the item's copyright could not force the owner of the actual item itself to set a specific price for 
the item to be sold. Although they would be the owner of the copy, they didn't own the copyright of the film itself. The studios felt the need to challenge these film collectors because they felt that the copyright of their own materials overrode what was found in the Bobbs-Merrill Co. v. Straus (1908) case (Vile). Although the "first sale" doctrine should have allowed the collectors to be protected, the studios were still able to seize hundreds of films for infringing Federal copyright law (Bartok \& Joseph 2-3). Essentially, these collectors were selling copyrighted material that were owned by the studios. Theaters did not purchase prints when they would choose to run a film from a certain studio, they paid the studio to rent a particular title. Once the screening was over, the prints were supposed to be returned to each studio (Novak). Due to the fact that these films were never legally purchased by a seller who was associated with the studio, these were considered to be pirated materials.

The libraries built up by collectors were no longer safe as the FBI, Justice Department, and MPAA became involved in bringing them to court. Originally the MPAA (Motion Picture Association of America) started out as a trade association, which focused on censorship and rating films on the suitability of their content. However, as technology changed and collectors began to get prints, their concerns shifted towards copyright infringement and piracy (Madigan). What was so special about these home movie libraries? They not only contained circulating prints of prominent titles that were most likely screened in theaters, but positive prints of films that were most definitely copyrighted by studios. One of the premiere cases brought to court was by a man named Evan H. Foreman who bought and sold commercial film prints. Foreman ran a $16 \mathrm{~mm}$ catalogue called $16 \mathrm{~mm}$ Filmland where enthusiasts could purchase prints. The studios (MGM, Twentieth Century Fox Film Corporation, Walt Disney Productions, Universal Studios 
Inc., and United Artists Corporation) got wind of Foreman's business and decided to sue him for copyright infringement (Bartok \& Joseph 1). The claims against Foreman were as so:

"These actions, according to the plaintiffs, constitute an infringement of their copyrights because they were without authority from the plaintiffs. In addition to these allegations of infringement on specific films, the plaintiffs further claim that the defendant committed other infringements by dealing in and selling positive prints of other copyrighted motion pictures belonging to or released by the plaintiffs" (Justia US Law).

The studios wanted to bar Foreman from collecting and selling prints, but in an ironic twist it was found in court that prints were actually being junked or sold to various TV stations.

Studios were found to have created contracts with television stations, which allowed them to purchase prints and send them to any of their stations. For instance, Columbia Pictures sold prints to salvage film dealers for payment as well as to film libraries throughout the US. This resulted in the legitimate sale of $16 \mathrm{~mm}$ films to be affected. Foreman was not charged with violating copyright infringement in that the studios were unable to prove that he violated such law. Their previous dealings with other parties made their claims less legitimate in court and Foreman did not duplicate, steal, or lost (Justia US Law). Due to the fact that the studios themselves utilized the "first sale" and put prints into commercial commerce. Still, the court battle that he was put through killed his catalogue and the ability to deal film prints (Bartok 10-11). This also scared other dealers in collectors into never discussing their collections, forcing much of it to go even more underground. It appears that the studios only cared about reprimanding these collectors for the sake of money. Since they weren't benefiting from the sale 
of these prints they wanted to stop the people who were. The studios wanted to gain control of how film enthusiasts could access content. The ability to watch "older films" was limited in that you could only see what was being rerun on television stations or through a repertory screening. Owning these prints was the only way for users to be in control of what they view and how they view it without studios having any say. The seizing of copies of film prints is a violation of the "first sale" act and posed a threat to the libraries of collectors. A New York Times article from 1975 claimed that many of these collectors had bootleg film prints that were duplicated, which is illegal (Nordhiemer). Of course, there were dupe prints, but many of the collectors in Joseph's book did not copy films, but simply collected the prints that were dumped by the studios. Even the libraries of celebrities were not safe--actor Roddy McDowell's film collection was also seized by studios in 1974 (Nordhiemer). The FBI ordered a search warrant for McDowell's collection which contained thousands of videotapes and hundreds of $16 \mathrm{~mm}$ film prints. Much of his collection contained many of his own films that he later transferred to videotape. The FBI seemed more alarmed by the fact that McDowell had taped much of the content off of television (Nordheimer). Meanwhile, people were creating state of the art screening rooms, which had not been seen before.

Although collecting $35 \mathrm{~mm}$ commercial films was more for the most dedicated film collectors, this shifted the meaning of the home movie library in new ways. First, this was the time in which the "home movie theater" really began to come into fruition. Rather than just projecting a film in a living room onto a blank wall, collectors with extra money could create immaculate screening rooms. Film scholar David Borwell describes the lengths collectors would go to: "Some went with curtains, masking, auditorium seats, popcorn machines, and other 
amenities" (Bordwell). Secondly, the films that they were collecting were full, feature-length films that were meant to stay in the home movie library (illegally). Many $16 \mathrm{~mm}$ films that were purchased in the early days of home distribution were too expensive to purchase and the early $8 \mathrm{~mm}$ Castle Films weren't feature-length films. Another big thing that would forever plague the home library from the 50's and onward was the war between film collectors and the studios. Since $35 \mathrm{~mm}$ films were illegally obtained, copyrighted material, the studios became invested in stopping the theft of film titles. As we will see, the battle between the film collector's library and the studios has continued into the 21 st century. Although the format would change over time, the issue of piracy would remain the same (Bordwell). Eventually, studios would focus less on film-based piracy and switch to investigating people for pirating videotapes. However, film collecting didn't die off right when videotape came on the market. Up until the 90 's, $35 \mathrm{~mm}$ prints remained of higher quality than earlier videotapes. Once the analogue tape technology became the standard for home distribution, film collectors began to invest in collecting tapes due to the ease of playing a videotape and the cheap cost of obtaining them (Bordwell).

The year of 1975 proved to be a watershed year in terms of technology and copyright. The new library contained sleak, looking VHS and Betamax tapes rather than projectors and film prints. Tapes became the new standard for the home library. Additionally, the hardware used to run the tapes changed the home library forever. With the advent of VHS tapes, cinephiles were allowed more access than ever before to their favorite films and television shows. Before film enthusiasts either had to either have access to prints or a television to watch their favorite films. What was so unique about this format was not the VHS tapes themselves, but the player that was needed to operate them. Although the video cassette recorder had been around in the early 
seventies, the inclusion of tapes into the home movie library did not arrive until 1975. Klinger noted that the VHS tape arrived on the scene in 1975 and that its user-friendly manner made film collecting more democratic (88). Essentially, Betamax and VHS are one in the same with the only differences being the quality and tape length--Betamax having the sharper image quality and VHS dominating in recording time of two hours (Greenberg 3). Betamax was the first to really land itself in people's homes. Scholar Joshua Greenberg stated that Sony was the first to revolutionize the home movie market through framing the VCR as a time-shifting mechanism (2). Before the DVR, people could purchase a number of blank tapes and they could fast-forward, pause, and stop their favorite programs using the VCR. VCR users could also record live television, which could include some of their favorite films or sporting events. People no longer had to worry about missing their favorite TV show. The main marketing ploy for the VCR was that it allowed those who owned them to maintain ultimate control over their libraries. Now that they could record their favorite films, they were now in control of their time and no longer had to rely on network television stations (Greenberg 2).

Eventually VHS and VCR went into two different uses--one that I label as democratic and the second as less democratic. First, the VCR was labeled as a time-shifting device and then it was marketed by studios and producers for consumers. Instead of recording movies off of network television, studios could assert more control over the market by selling tapes with films already on them. Both pathways added to the home movie library, but the VCR itself allowed viewers unregulated access to content. 


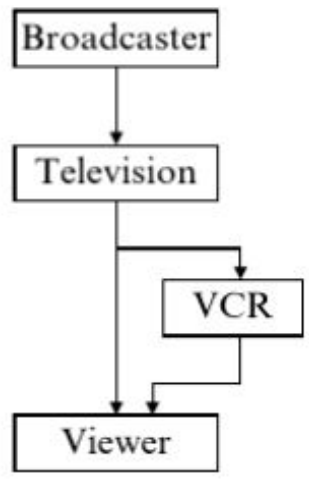

Timeshifting

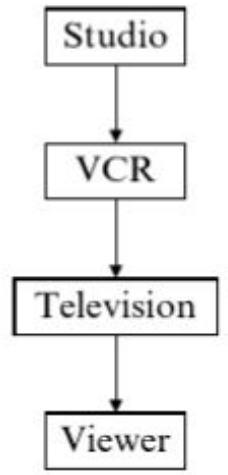

Movies-on-Video

Image: Greenberg's chart on how the VCR was utilized in the home (13).

Barbara Klinger claims that the film collector rose to prominence with the arrival of VHS tapes (55). However, I've shown that the film collector had already well existed prior to the arrival of VHS and Betamax. However, the ability to tape content allowed cinephiles to curate their own archive, which wasn't possible before. For example, a woman taped the news for 24 hours a day until she passed away in 2012. She had over 70,000 tapes which contained historical events such as the Moon Landing, JFK assassination, and the 1979 Iranian Hostage situation (Kalia). Enthusiasts created lists of the tapes in their collections and some would update them weekly (Greenberg 57). Due to accessibility reaching an all-time high in the late seventies, a community of tape collectors flourished. Many "videophiles" met through a newsletter publication called The Videophile's Newsletter. This newsletter was started by a lawyer named Jim Lowe and its aim was to connect collectors who wanted to swap tapes. Originally the goal was to swap Sony Betamax tapes, but this changed when VHS won out as the standard format (Lowe). Greenberg elaborated on this community further: "In some cases, hobbyists sent "video letters," personalized video tapes recorded for one another using video cameras in which they 
would talk about their lives and give virtual tours of their homes. Taping parties were common" (24).

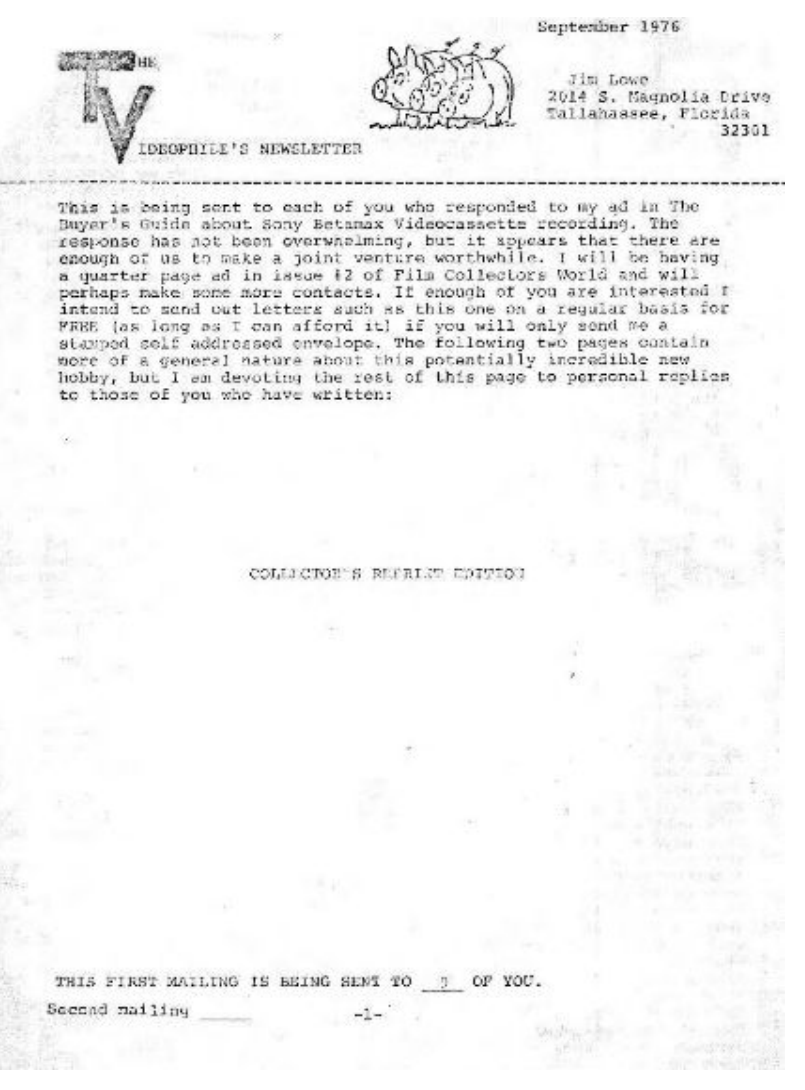

Image: Issue 01 of The Videophile Newsletter (Lowe)

Just like those film collectors obtaining $35 \mathrm{~mm}$ prints in salvage yards, an archive is being built within the home by the cinephile. The owner was in control of his or her own collection and could organize them any which way (date, genre, title). The ability to tape anything that came on the stream allowed people to be able to rewatch things they wouldn't normally be able to see. Newscats, sporting events, and public access television would never be sold pre-taped in stores. Betamax and VHS also allowed for more accessibility that was needed in order for the everyday person to be able to tape things off the television. This has resulted in the equipment and tapes were more affordable and attainable for the average film hobbyist. It was more economical and 
the time-shifting feature was well worth the expenses for collectors (Greenberg 20). Although some studios were unsure whether or not it was legal to tape copyrighted material off network television, collectors openly engaged in publishing lists of their collection, going to video collector's conventions, and hosting video-swapping parties (Greenberg 26).

However, this did not stop studios from going after collectors on the basis of copyright infringement. If a hobbyist were to record a film off of one of the network stations the studios felt that this violated copyright. Roddy McDowell's film collection that was seized by the FBI contained many videotapes of feature films (Nordheimer). Another notable court case that occurred was when the president of Universal pictures decided to unleash a lawsuit on Sony's Betamax to stop all sales of tapes. Many collectors felt like this was an infringement on their freedom to create their own libraries and they even created the Home Recording Rights Coalition in order to defend themselves (Mullin). Recording protection tabs was placed on the corners of the tapes in order to prevent people from taping copyrighted content (PSAP). Eventually studios began to entering the VHS market by distributing their own movies.

Pre-recorded videotapes didn't arrive on the scene until 1972. Before they were sent to video rental stores, they were purchased by consumers through businesses who had agreements with the studios. Similarly to the studios renting out $16 \mathrm{~mm}$ or $8 \mathrm{~mm}$ films to consumers, the businesses would sell a VHS tape (sometimes in a package with a VCR) and the studio would get a royalty payment. This didn't allow studios to be in complete control of their products, but they did make a lot of royalties off of consumers paying for these tapes. Tapes were usually purchased at hardware stores or electronic shops. Studios were able to make large royalties 
because the first couple tapes that were sold cost upward of $\$ 80$ (Greenberg 53-54). Tapes were seen more as an accessory rather than the main attraction; they were essentially there to sell the hardware (VCR, Betamax player). In 1978, studios began to create their own home video divisions. Big players such as Disney began to join the market and they were responsible for producing and advertising their tapes (Greenberg 57). Although studios were getting into the action, they still didn't have complete control over their consumers since they could now own their own copy to watch anytime. However, there were special cases of the studios using certain business tactics to scare customers into purchasing material that had a limited availability. Walt Disney's home media Division, Walt Disney Studios Home Entertainment used the term "Disney Vault" in order to suspend sales of certain films by putting them in moratorium for ten year gaps. Other home video divisions repeated this tactic with big-name Hollywood films. This caused certain titles to become more expensive, saught after collector's items. This tactic continued on into other media such as DVDs and Blu-rays (Tuttle).

In 1979, Paramount was one of the first studios to create an agreement with a business that was to exclusively sell and rent their videotapes. The business was Fotomat, a photo-developing place. This was a groundbreaking opportunity for consumers because they were able to own their favorite Hollywood films without having to tape them; however, they could only buy Paramount's films through Fotomat. Eventually other studios began to give in and have their films be sold through other hardware stores and even movie theaters. By 1986, there were 25,000 video store retailers across the United States (Greenberg 77). Store owners were able to rely on rental revenues to pay for the tapes they were renting out. Consumers were also able to pay a small price for a one-time experience and studios did not have complete 
control over their libraries if they decided to purchase their own copy. Up until the 1980s and 90s, renting a videotape was much more financially feasible than buying expensive equipment. Eventually, the prices of the tapes lowered, which encouraged consumers to buy more tapes rather than rent them (Klinger 59).

The VCR and videotape affected the home movie market in a way that was never seen before. The hardware allowed for people to record live television for the first time and they could create their own archive by collecting newcasts, movies, sports, and so on. In a similar fashion to those who pirated $35 \mathrm{~mm}$ and $16 \mathrm{~mm}$, taping content off television caused the studios to shift their focus to this new issue. At the same time, a community was created, similar to the underground collectors of celluloid. People of all different classes were also able to own some Hollywood films and television shows that, before, they would have not had the privilege to access. For the first time, actual brick-and-mortar stores were set up in order to let consumers rent out tapes at low prices. The equipment was easier to understand and the prices steadily became more affordable over time. Its legacy carried on through more unsuccessful media, but consumers were able to add new formats to their growing libraries. VHS tapes were not meant to have a long shelf live or the image highest resolution. In fact, it was discovered that VHS tapes were only good for ten years. Within the last decade, many tapes have degraded, resulting in a worse image quality. Several types of tape degradation have been noted: binder deterioration, poor playback signal, demagnetization, and edge damage (Wheeler \& Brothers). The subtle deterioration of video tape and the arrival of DVD in the 90's resulted in a shift in the home library to digital. 
One of the other formats that was advertised towards the home consumer that arrived around the same time as VHS was Laserdisc. Laserdisc arrived on the market in 1978 and its hardware was manufactured by the electronic manufacturer Phillips. Phillips teamed up with the record company MCA because they owned the largest catalogue of films at the time (NYU). Laserdisc was groundbreaking in that it created a stepping stone towards digital media. The technology was a mix of both analogue and digital. This allowed for some superiority over VHS, but of course there were also some drawbacks. For the movie collector, the laserdisc opened up an entirely new world. Discs could contain special features, bloopers, and behind-the-scenes footage from some of their favorite films. Viewers would have never been able to access footage quite like this prior to Laserdisc. Users could also avoid having to fast-forward to a specific scene, they could simply choose a certain scene since the discs were chapter-based. Discs were also a lot cheaper than VHS tapes because the plastic used to construct them was so easily accessible (Mutants). Unfortunately, despite the fact that they were a big stepping stone into digital media, the technology didn't last due to the discovery of an easier and higher quality format. DVD and Blu-ray was and is the last physical format for the home video market (DeMuro).

Barbara Klinger and Joshua Greenberg's works that focus on the home library stopped with the advent of DVDs and Blu-rays. This mainly has to do with the fact that their publications were published before streaming services arrived on the scene. DVDs are different than other formats previously discussed in that it's completely digital. With a VHS tape there is actual magnetic tape that has tiny magnetic particles that contain information. There are three layers on the actual tape: the binder layer, the substrate layer, and the backing layer. The binder layer is the 
one that contains the information that is run against the playback sensor. The other two layers are there for strength and to protect the binder layer (ScanCafe). Analog is the method that is used to record information via an electronic signal and in doing so alters magnetic particles on the tape (Wheeler \& Brothers). Digital is the method of storing information on a disc based on a dot pattern on its surface where the data is then translated. Digital data is then stored on the disc and is read through a laser that reads the disc in a circular motion. They can be found in surviving video rental stores next to VHS tapes or for purchase at almost any department store. In a similar way to the film-by-mail exchanges of the 1910s and 1920s, companies such as Netflix mail out DVDs from a catalogue for a monthly subscription (Greenberg 157). One of her main reasons behind Klinger's statement of democracy in the home is the ability for viewers to rewatch films anytime they please. With the arrival of digital physical media, the ability to rewatch things has been made more accessible than it has been in the past. People of different economic statuses are able to build their own libraries. The hardware has become less mechanical and is easier to operate. Setting up a home movie library is more cost efficient. You didn't have to be a zealous fan of cinema in order to have your own home movie library. The cheaper prices for equipment has made creating a screening room more achievable for the average viewer. The films presence is diffused by their small size and the fact that they can be easily placed throughout the house. Collectors can categorize their DVDs in their home library in many different ways: genre, director, collector's editions, actors/actresses, and so on (Klinger 57). DVD became favored over VHS because of its higher quality for a lower cost and the fact that digital technology was becoming overwhelmingly popular at the time. The marketing of DVDs became more sophisticated; collector's editions, special editions, director's cuts, special features signifying 
these copies as privileged (Klinger 59-60). Hollywood shifted to distributing DVDs for several reasons: cheaper cost, higher resolution, and stronger durability than VHS, which resulted in more profit. Still, studios continued to make sure that physical media was still being controlled through them. According to Greenberg, studios learned from their mistakes with VHS and regained their control over their own products through DVD:

“Unlike videocassettes, movies on DVD are encoded with a proprietary algorithm called Copyright Scrambling System (CSS), which is created, owned, and regulated by the DVD Copy Control Association (DVD CCA), a consortium of movie studios and hardware manufacturers. Since studios only release DVD movies that are encrypted with CSS, they can essentially control the format through the DVD CCA" (157)

Due to a lot of special features in television sets and DVD players, it's difficult for people to watch pirated movies and television shows on the digital format (ScientificAmerican). However, people are still able to duplicate DVDs containing copyrighted material. This can be done using a DVD ripping program via a computer. If someone purchases a copy of a Hollywood film that has a copyright label on it, duplicates the disc, and sells it then this is illegal. The law doesn't care too much about someone duplicating a DVD for personal use within their home (TopTenReviews). Studios just don't want to lose profit because someone duplicates their films to make money off their product. Blu-ray discs were supposed to replace DVD as the home distribution standard. Blu-ray discs arrived in the early 2000s and were developed by a group of media manufacturers. These discs have five-times more storage capacity than DVD and have high definition playback. Blu-ray players use a blue laser to read disc information as opposed to the red DVD laser, which meant that people had to purchase Blu-ray players (Blu-ray.com). A 
possible disadvantage of Blu-ray is that it is more expensive than the average DVD. Customers are paying a higher price for a higher quality disc. Unfortunately, Blu-rays arrived too late on the scene and by 2008 sales for both discs had declined by $86 \%$. There are several reasons for this continuing decline: there has been a rise in customers buying videos-on-demand via cable, buying digital copies, and the launch of streaming services. Since 2011, the streaming industry has boomed and DVD sales have continued to slip well into the year 2018 (Whitten). The arrival of streaming has created a tremendous shift in the home library. The slow transition away from DVD and Blu-ray has called into question whether or not physical media will become obsolete entirely.



\section{Source: Sarah Whitten, CNBC}

Streaming is an entirely new phenomenon that is so different from its predecessors. In fact it's so new that there is hardly any scholarship written on the subject. What is a streaming service and how do people consume their favorite film and television shows through it? How is it different from other forms of media? Instead of a film reel, tape, or disc, the film is contained on a digital file. The general definition of streaming is when a viewer plays a movie on one device 
while the media is actually stored on a separate device; the media may be stored on a computer or drive. However, a streaming service can also be a website in which you pay to stream various movies and television shows on your computer, phone, or media player (i.e. Blu-Ray player, Roku Stick, or Chromecast) (Gonzalez). With the arrival of streaming, the home library has become something that one can no longer physically see and hold, much like you would with a film reel, VHS tape, or Blu-Ray. There is no need for hardware or equipment; users can access streaming services through any electronic device with a network connection. Since consumers don't own the physical film there is no home movie library because it is no longer necessary in order to rewatch your favorite film. However, consumers could still build immaculate screening rooms in order to stream their favorite films. The provider of the service is providing you with the content through an internet connection. Providers such as Netflix, Hulu, HBO, Disney+ require viewers to pay a monthly subscription in order to access their film and television libraries. Unlike previous services that have been examined in this paper, this is the first time in which film lovers have paid for a subscription to an entire library rather than paying for an individual title. This is also the first time in which viewers have paid for a film that they weren't going to be able to physically own. This has resulted in a significant change in the home library that may cause it to go extinct.

Streaming is just another major shift in the film industry. A majority of this paper has examined a number of these shifts. The "Streaming Revolution" has currently changed the way in which people view and collect movies within the home. Instead of licensing a film to cable channels via video-on-demand, video rental stores, and home distribution companies, this is one of the first times in which big studios are selling their own content to consumers (Barnes). One 
of the differences in this cultural shift is that a film that is streaming is not saved onto your computer and can't be shared. These companies are no longer selling consumers a physical product. The ability for viewers to create a watchlist or queue of content provided by the services is the only way to keep track of what content you want to watch. Unfortunately, the movies that are on your watchlist may not be available since uses are not in charge of what is available on the service. In reality, the company or corporation who owns the streaming service is in charge of what content is available (Gonzalez). For example, streaming services such as Netflix have paid over $\$ 80$ million to keep certain shows on their streaming website (Adalian). According to their website, they don't renew title if there is a lack in popularity or if it is seasonal (Netflix). In fact, in 2015, an article in the International Business Times reported that more than 135 titles were to leave Netflix in the month of October (McCarthy). The competition between streaming services has caused notable startups to shutdown, which may serve as a reminder that it may be dangerous to put so much weight on these websites. Content has also become more exclusive, meaning audiences only have access to certain anticipated shows if they subscribe to whatever service is licensing the content. For example, a notable merger between television station Turner Classic Movies and film distributor Criterion created a classic film streaming service. The idea that streaming services are tangible came to a head when their streaming service, FilmStruck, was shut down by Time Warner (owner of Turner Classic Movies) and AT\&T, who recently merged with the company (Brody). The death of this streaming service was a wake-up call for its users and reanimated the physical media v. streaming debate. Paying for access to this data doesn't mean that the service isn't revocable. A quote from New York Times writer Richard 
Brody advises fans of cinema to continue their creating a home library: "Whatever's worth revisiting over the years is worth owning--whether in physical media or a digital file" (Brody).

The collector that Walter Benjamin references in his article "Unpacking My Library" will no longer be present during this "streaming revolution". It's no longer necessary for collectors to acquire different prints, tapes, or special-edition DVDs in order to watch their favorite films. Creating a home theater didn't require as many accessories because it reached a new level of portability. The cinephile doesn't need to rely on a VCR, laserdisc player, or DVD/Blu-Ray player because all that is needed is a computer or cellphone with a wireless connection. You no longer have to go out and rent a film from a rental store and you can watch your favorite shows wherever you are. Blogs list other apparent pros to streaming such as content being more readily available, current subscription rates are cheaper than cable, and for those who pay for the service are guaranteed ad-free content (Marius). One of the positives mentioned is that streaming services allow for more access to content that has been forgotten. Criterion recently came out with their own streaming service, which came out on April 8th. The channel's mission, according to its president Pete Becker, is to cater to classic film fans by providing them access to obscure media (Sims). The quality of the digital transfers of film are so pristine that there's no comparison to watching the same content on a VHS tape or DVD. Netflix has even used their platform to reanimate television shows that were thought to be dead and providing them with a new home (Acevedo). Teachers are able to take advantage of these services so that students can watch the same film without any hassle. Criterion and the educational service Kanopy have been the answer for those in academia. More libraries have also been available as more streaming services have popped up. In the year 2019, many companies saw how viable the market was for 
streaming services and they began to jump on the bandwagon. Film studios in particular are aiming to create their own services in order to compete. They may also see this as an opportunity to regain control over their content after struggling to do so with physical media. Disney and NBCUniversal have announced their own streaming services in order to compete with Netflix, Hulu, and HBO (Sherman and Boorstin). Warner Brothers also announced its own streaming service, WarnerMedia, in June 2020. The company plans to charge users a higher fee than its competitors at \$16 per month (Nguyen). However, it's well-known in the archive community that not every title will be transferred when formats changes occur. A lot of titles that are available on tape or DVD won't make it onto streaming services. Many services aren't concerned with foreign, arthouse, or classic films. A professor of communications at the University of Technology Sydney blames this on the complicated nature of copyright laws and streaming services who want consumers to spend their money on subscriptions without knowing what is in their libraries. Copyright also hinders many titles from even reaching streaming platforms (Moran). If a consumer is looking for obscure titles, it may be best to skip out on streaming and visit one of the few video rental stores still left in the country.

Users are now offered a plethora of libraries to subscribe and unsubscribe with the click of a button. Currently, there are over 271 online streaming services for consumers to choose from (Chow). Unfortunately too many options can create the opposite effect. An article published on August 8th, stated that customers were becoming frustrated about managing their multiple subscriptions (Fluent). Advertisements for streaming services list a number of titles that are going to be available if a consumer subscribes. In reality, there isn't really a single, 
comprehensive library available because there are spread out among various services. One of the major reasons for consumers frustration with streaming is that they don't actually own any of the content they are paying to see. Ownership of content is also becoming more and more complex as more services begin to pop up. This is mostly due to the fact that media consolidation has come into play within the business world of streaming. Studios and other corporate entities are beginning to take back more control over the content, forcing viewers to pay more for titles they will never own.

In a similar fashion to the media consolidation of the early studio system, studios are looking to regain control of all of their own content again. Prior to the wave of new streaming services, it was customary for the license holders of certain film and television shows to license content to general platforms (Netflix and Hulu). Licensing is already a very tricky subject to understand, but before Netflix started creating its own content it relied mostly on licensing agreements to acquire content. The company pays a fee to whoever owns the rights to the film or television show in question and a contract is established. Usually there is a certain length for each contract--a show could play anywhere from two to five years and once the contract is up the content can be taken off the service or it can be renewed (Alexander). Issues with licensing have a direct impact on viewers because they can't control whether content stays or goes on the platform they've subscribed to. It doesn't matter if a user has been looking forward to rewatching Friends or The Office on Netflix, the breakup of licensing agreements will cause more content to leave general streaming platforms. From an observational standpoint, it seems the tipping point in companies realizing the importance of locking their own content behind their own paywalls came when Netflix and Hulu began creating their own 
films and television shows. Both platforms were able to save money by avoiding licensing, allowing for more money to be put towards creating in-house productions (Levy). Prior to creating their own content, licensing was the greatest expense for Netflix with them paying astronomical prices to keep certain shows (i.e. spending \$100 million to WarnerMedia to keep Friends) (Lee). Streaming services are also no longer a joint ownership between studios and other corporations, meaning content from all different libraries won't be common practice in the future. Hulu at one point owned by Disney, 21th Century Fox, Comcast's NBCUniversal, and TimeWarner. As of May 2019, Comcast sold their share of Hulu to Disney and Disney subsequently purchased 21 st Century Fox, meaning that Disney owns more than half its share of the streaming platform. As a direct result, NBCUniversal decided to start their own streaming service with WarnerMedia trailing closely behind them (Disis). NBCUniversal is supposed to unveil their service in 2020 and is different than Disney+ (Disney's service) and WarnerMedia in that it will be free for cable subscribers. Those who do not pay for cable will have to pay a monthly fee. The CEO of NBCUniversal Steve Burke made it clear that users will have to become accustomed to subscribing for multiple streaming services (Steinberg and Littleton). With the announcement of this new service there was some bad news for users as it was noted that one of Netflix's most popular shows The Office was going to be taken back by the original rights holders (NBCUniversal) once the licensing agreement expires at the end of 2020 (Alexander). Many shows that can currently be streamed on Hulu or Netflix such as 30 Rock or House will eventually end up on NBCUniversal's new streaming service (Alexander). Users of these services have been caught in a tug-of-war over content. People who once had "unlimited access" to content for a small fee per month were losing their favorite shows because the owners 
wanted to take away content from general streaming platforms. Even nonprofit entities are taking away content from general streaming platforms. Parents were upset when Amazon removed a children's show called Daniel Tiger's Neighborhood from their platform. The animated kids show belongs to PBS, a nonprofit broadcasting network, and they were taking back their own content to create yet another streaming service. When parents complained to Amazon about the removal of the show they simply responded with "our selection changes from time-to-time" (Lakritz). Another big shift occurred when Disney announced they were moving all of their titles that were on Netflix to their own streaming service (Alexander). These big changes in accessibility have caused people to be uncertain about where their favorite shows will be in the next few years. Even television shows that have been broad casted on cable channels are being hoarded behind paywalls. The beloved show The Simpsons will be exclusively streamed on Disney's platform (Otterson). Although there will be many features available for viewers to watch on new service, they aren't releasing certain controversial films such as Song of the South. The company will also be omitting a scene in Dumbo in which a crow named Jim Crow is featured. Disney CEO Bob Iger noted that releasing this content on the streaming service would be bad for their shareholders (THR). Not only are companies locking content behind paywalls they are refusing to release more controversial content that deserves to be viewed for historical purposes because it's bad for business.

This isn't the first time Disney has refused their customers access to their content. Marketers came up with a way to create fear among consumers that their favorite Disney movie would no longer be available by "locking" it in a vault. Movies would no longer be sold for years until a new special, pricey edition would be available for purchase for a limited time. People 
were more likely to buy these films if they are scared that they will no longer be available (Tuttle). Disney announced that thirty-four films that were in the vault would all be released on their streaming platform (Alexander). Of course, this doesn't include Song of the South, but this has caused Disney+ to gather a lot of momentum. People on social media have stated that they may consider joining the service now that the Disney vault films were going to be released. This does not mean that the company won't create a similar vault system again. In fact, they have more control over their subscribers because no one will own the physical copy of the films they are releasing. In October of 2019, an article covered Disney putting Fox films into the "vault", stopping repertory theaters from being able to screen any film from Fox's catalogue. Theater owners are being told that they no longer can book films from Fox's library, which is now owned by Disney (Seitz). Although this doesn't have to do with the home library, this tactic by the company has caused film fans to ask, what's next? Will these Fox films be added to Disney+ or will they remain in the vault for a number of years? Once they take content off their streaming services, people will be left with no copy of the film until it appears again on the service. As more mergers continue to take place, consumers are having to question whether they will even be allowed access to their favorite films and television shows.

Throughout this thesis there have been many examples of the collector having to fight with studios over accessing certain films and television shows. Of course, the studios had more power over the entire industry at a time when film pirates were still buying off prints from salvage yard workers. The final nail in the coffin for studios was the 1948 Paramount Decree, which was a court case that stated that studios could not own production, distribution, and exhibition (Bailey). The studios were forced to part with one facet of the industry and they chose 
to sell of their theaters, allowing for them to keep their production and distribution arms. This allowed for more independent companies and be able to compete in the movie industry. Immaculate movie palaces owned by the studios were replaced with multiplexes and independent theaters in the 1970s (Johnson). In today's standards, you could easily replace movie palaces with streaming platforms. Movies are being "released" on streaming platforms alongside regular runs in a theater. As technology has advanced, the way movies are exhibited has changed. Movies can now also exclusively be exhibited via streaming platforms, so I would define these platforms as exhibition spaces. Streaming services are essentially a virtual exhibition space, so wouldn't this violate the decree? By the definition of this paper, this would be a correct assumption. This is a correlation I see lacking in many news articles that discuss streaming. With the recent acquisition of the Fox library by Disney, the media has begun to take notice on how much of the industry the company now owns. According to an article written in 2017 , the author encouraged people to take a closer look at all of Disney's assets. Currently Disney owns these companies: "Pixar, Lucasfilm, Marvel Studios, the Disney/ABC Television Group (which includes $\mathrm{ABC}$, ABC Family, and several local ABC affiliates), ESPN (including not only multiple ESPN networks but also radio and publishing arms), A\&E Networks (including A\&E, the History Channel, and Lifetime), and a 30 percent stake in Hulu” (Bailey). The Paramount Decree clearly stated that diffusion of film should not be completely controlled by a single corporate entity. Recently, Variety published an article stating that the DOJ Antitrust Division will be looking into revising the 1948 Paramount Decree to see if there needs to be changes made to fit the current business dynamic (Johnson). Another article from Deadline assures readers that it's less likely that studios will rush to by chain theaters if the decree is terminated 
(Johnson). Whether or not studios will buy up theaters should be the least of the industry's worries. The termination of the decree will most likely allow for even more media consolidation on multiple fronts. In actuality, the fact that major studios now own a virtual exhibition platform already demonstrates that studios have found a loophole in the decree, which could be easily achieved since it doesn't reflect current industry practices. A comparison could be made between Disney owning a stake in multiple services as well owning their own service and studios owning multiple theater chains. This could cause general and startup streaming services to be eliminated from the competition. This and the fact that Disney is banning repertory screenings of Fox films shows that they are already trying to control and eliminate the competition online and offline. There should be concern in the studios being able to buy up other businesses once the decree is eliminated. Another tendency of Disney is to put certain titles in moratorium and with the amount of content they now own, it's more than likely that titles will be harder to access certain titles unless the consumer is subscribed to the one streaming platform that they own or other platforms that they have a stake in. A constant theme in regards to the home library is the constant tug-of-war between the studios and control over physical media. Studios have now found a way to be more in control of their content, which they struggled to achieve in the past. The more media consolidation there is, the harder it will be for consumers to be in control of their own libraries. Owning physical media is more important than ever because allows for some freedom in a time where that is becoming compromised because of a cultural shift.

One of the most reported positive features of a streaming service is its apparent low cost. Users pay a monthly fee in order to access a plethora of movies and television shows. The 
monthly fee to access Disney+ is only $\$ 6.99$ a month, which is considerably cheaper than other services like Netflix or Hulu. However since certain content is no longer available on Netflix or Hulu, users have to choose which libraries they can afford to have access to. Libraries have become more fragmented and there are too many options to choose from. The low monthly cost of these services has influenced people to stop paying for cable in hopes that their expenses would go down. The average cable bill can be upwards of $\$ 100$ a month, which put side-by-side next to a bill that you would get for multiple streaming services doesn't seem comparable. However, with the rights wars and libraries becoming more fragmented, people will more than likely be subscribing to multiple streaming services rather than just one or two. If you add all the prices of the current streaming services together, the cost, roughly, adds up to \$93.92. This estimate doesn't even account for half of the streaming services that have just been announced for the year 2020. A marketing website actually created a calculator so that consumers can see how much they will be spending per month on their subscriptions (Shaw \& Marriner). If you subscribe to up to eight services, you're looking at a total cost of $\$ 116 /$ month bill. The website notes that the average household bill currently tops of at $\$ 50$ a month and that the average person only plans to subscribe to one or two services. With the recent media consolidation and locking content behind paywalls, it could be more difficult to only stay subscribed to two services in the near future. Essentially, viewers are getting a refurbished cable bill. Users don't have to subscribe to all of these streaming services listed, but if they want access to certain libraries they are most likely going to have to subscribe to multiple platforms. With auto-pay it can be easy to not realize how much you are paying per month for these 
services. Viewers will have to be prepared to begin to pay for multiple services if they want access to their favorite films and television shows.

Some consumers have opted out of subscribing all together due to the annoyance of having to subscribe to multiple services. A recent study conducted by a comparison website showed that out of 1500 consumers about $18 \%$ to accessing content via illegal streaming or file sharing services. Additionally, $37 \%$ of people felt overwhelmed by the amount of streaming options and $48 \%$ felt that the price was one of the biggest problems with having multiple services. Consumers only have so much income to set aside and having to subscribe to multiple services causes money to be tight (Bode). Another reason is that content is becoming part of exclusive deals. Certain shows such as Game of Thrones are being produced only through streaming services. In order to watch new episodes you'll have to subscribe to the service. This has pushed many to drift towards piracy. BitTorrent, a peer-to-peer file sharing software, has seen an upstream in traffic by $26.83 \%$ as recent as 2015 (Cullen). The failure to meet expectations also drives consumers to find an alternative source for entertainment. Users of BitTorrent or other torrent software don't have have to wait for an episode or film to show up on a streaming service. Content can be shortly after an episode airs (Bode). One of the main goals of streaming was to eliminate the cost of cable by subscribing to one, general streaming service for a small fee. Now that this is no longer the case, the cost of streaming is getting as an expensive as cable. Since neither cable or streaming is desirable, pirarcy seems like the best option (Hofstra). For now, these services don't seem to concerned about piracy, which is most likely because they're too busy competing to "win" the "streaming wars". If these services aren't too 
careful, they will most likely drive people away, resulting in more consumers choosing piracy over streaming.

Predicting the future of media is always complicated. As of 2019, the streaming revolution is just picking up steam. A recent study predicts that by the year 2022 every major broadcaster will be offering their own streaming service (Bode). This will most certainly cause greater tension between cable between the network and the streaming service operators. Additionally, piracy will continue to skyrocket the greater the competition gets. Right now it seems that streaming services are becoming the preferred way to watch film and television within the home. Physical media's prevalence seems to becoming less and less as time goes on. With DVD sales declining and consumers willingly selling their libraries off to video rental stores, it doesn't look too positive for the home library. Once consumers give away their libraries, they are giving up their freedom to be in control of how they consume content. The owners of the services are now choosing when you can and can't have access to things. We already see this happening with Disney when they acquired Fox's library. Studios have always struggled to maintain control, but with streaming they have the upperhand. For the other reasons I've listed within this thesis, it is more important now more than ever to collect physical media. You'll avoid being caught in the fragmented streaming wars, having to pay the monthly costs, and being barred from exclusive content. Rather than consumers paying a monthly fee to rewatch a few of their favorite shows and films, they can make a one-time purchase and own the copy for as long as they desire. The next best option is to have digital files of their film and television shows that can be stored on a hard drive or personal computer. If consumers want access to their 
favorite movies for years to come, it's better to own it because it may not always be available again.

\section{Works Cited}

"5th Edition Catalogue of Kodascope Talking-Film Libraries". Published by

Kodascope Libraries Inc., New York. 1936. Archive.org

Acevedo, Angelica. "11 Shows Netflix Saved from Cancellation.” Insider. Insider, August 10, 2019. https://www.insider.com/shows-netflix-saved-from-cancellation-2019-8.

Adalian, Josef. "Why Netflix Spent $\$ 80$ Million to Keep Friends for Another Year." Vulture, Vulture, 5 Dec. 2018, www.vulture.com/2018/12/netflix-friends-2019-streaming-deal.html.

Alexander, Julia. “The Office Will Leave Netflix in 2021.” The Verge, June 2019, https://www.theverge.com/2019/6/25/18758714/the-office-netflix-2021-nbc-universal-str eaming-wars.

Alexander, Julia. "Disney+ Downloads Will Disappear from Devices If a Title Is Pulled from the Service." The Verge, Oct. 2019, https://www.theverge.com/2019/10/24/20930207/disney-plus-downloads-offline-viewing 
-star-wars-marvel-netflix-bob-iger.

Alexander, Julia. "NBCUniversal's New Streaming Service Could Spell Trouble for Hulu." The Verge, Sept. 2019, https://www.theverge.com/2019/9/18/20870783/nbcuniversal-peacock-streaming-wars-h ulu-netflix-office-parks-and-recreation-snl-exlcusives.

“American International Pictures, Inc. v. Foreman, 400 F. Supp. 928 (S.D. Ala. 1975).” Justia Law, https://aw.justia.com/cases/federal/district-courts/FSupp/400/928/1367313/. Accessed 9 Dec. 2019.

Barnes, Brooks. "The Streaming Era Has Finally Arrived. Everything Is About to Change." The New York Times, 18 Nov. 2019. NYTimes.com, https://www.nytimes.com/2019/11/18/business/media/streaming-hollywood-revolution.ht $\underline{\mathrm{ml}}$.

Beers, Brian. “Netflix’s Billion-Dollar Content Licensing Budget.” Investopedia, https://www.investopedia.com/articles/investing/062515/how-netflix-pays-movie-and-tvshow-licensing.asp. Accessed 9 Dec. 2019.

Birtac 17.5mm Camera/Projector | Science Museum Group Collection. https://collection.sciencemuseumgroup.org.uk/objects/co8084353. Accessed 9 Dec. 2019. Bode, Karl. "Streaming Exclusives Could Double Piracy Rates, Study Warns." Vice, 1 Oct. 2019, https://www.vice.com/en_us/article/xwe $4 \times 7 /$ streaming-exclusives-could-double-piracy-ra tes-study-warns. 
Bode, Karl. Study: Every Broadcaster Will Offer a Streaming Service by 2022. https://www.dslreports.com/shownews/Study-Every-Broadcaster-Will-Offer-a-Streaming -Service-by-2022-141445. Accessed 9 Dec. 2019.

Bode, Karl. "The Rise of Netflix Competitors Has Pushed Consumers Back Toward Piracy." Vice, 2 Oct. 2018, https://www.vice.com/en_us/article/d3q45v/bittorrent-usage-increases-netflix-streamingsites.

Bordwell, David. "Reeling and Dealing: Rescuing Movies, by Hook or by Crook." Observations on Film Art, http://www.davidbordwell.net/blog/2016/09/11/reeling-and-dealing-rescuing-movies-byhook-or-by-crook/. Accessed 9 Dec. 2019.

Brody, Richard. The Shutting Down of FilmStruck and the False Promise of Streaming Classics. Oct. 2018. www.newyorker.com, https://www.newyorker.com/culture/the-front-row/the-shutting-down-of-filmstruck-and-t he-false-promise-of-streaming-classics.

Cullen, Cam. Global Internet Phenomena Preview: File Sharing on the Internet Reverses a Downward Trend. https://www.sandvine.com/blog/global-internet-phenomena-preview-file-sharing-reverse s-a-downward-trend. Accessed 9 Dec. 2019.

DeMuro, Rich. "Flashback Friday: Take a Look at the LaserDisc." FOX6Now.Com, 1 Feb. 2019, 
https://fox6now.com/2019/02/01/flashback-friday-take-a-look-at-the-laserdisc/.

Glass, Don. What Is A Thaumatrope?

https://indianapublicmedia.org/amomentofscience/thaumatrope.php. Accessed 9 Dec. 2019.

“Edison's 22mm Home Kinetoscope.” USC Hugh M. Hefner Moving Image Archive, http://uschefnerarchive.com/project/edisons-home-kinetoscope/. Accessed 9 Dec. 2019. Enticknap, Graham, and Leo Douglas. Moving Image Technology: From Zoetrope to Digital. Wallflower Press, 2005.

FADEN, ERIC S. “CROWD CONTROL: EARLY CINEMA, SOUND, AND DIGITAL IMAGES.”Journal of Film and Video, vol. 53, no. 2/3, 2001, pp. 93-106.

Faiola, Ray. "UNIVERSAL SHOW AT HOMES.” Classic Horror Film Board, https://www.tapatalk.com/groups/monsterkidclassichorrorforum/universal-show-at-home s-t2220.html. Accessed 9 Dec. 2019.

Faubel, Christian. "ZoOHPraxiscope, Re-Inventing the Zoopraxiscope with an Overhead Projector." Journal of Science and Technology of the Arts, vol. 7, no. 1, Nov. 2015, pp. 21-28. artes.ucp.pt, doi:10.7559/citarj.v7i1.145.

Fluent. "Streaming Goes Mainstream: How to Win in the Crowded Streaming Services Space." Fluent, Inc., 8 Aug. 2019, https://www.fluentco.com/resources/streaming-services-whitepaper/. 
Gebrüder, Bing. "Instructive Optical Toys. Magic Lanterns, Dissolving View Apparati,

Sciopticons, Cinematographs, Large Collection of New Slides in Sets. Stereoscopes. Magnifying Glasses, Reading Glasses”. Nuremburg: Gebrüder Bing, 1906. Internet Archive, http://archive.org/details/Bing_InstructiveOpticalToys.

Gonzalez, Barb. "Is It Better to Stream or Download Media Files?" Lifewire, https://www.lifewire.com/difference-between-streaming-and-downloading-media-18473 72. Accessed 9 Dec. 2019.

Greenberg, Joshua M. From Betamax to Blockbuster: Video Stores and the Invention of Movies on Video. The MIT Press, 2010.

Hill, Paul, and Stephen Herbert. "Eadweard Muybridge and the Kingston Museum Bequest." Film History, vol. 10, no. 1, 1998, pp. 98-107.

"History of Edison Motion Pictures." Library of Congress, Washington, D.C. 20540 USA, https://www.loc.gov/collections/edison-company-motion-pictures-and-sound-recordings/ articles-and-essays/history-of-edison-motion-pictures/. Accessed 9 Dec. 2019.

Horak, Jan-Christopher. "Introduction to Film Gauges." UCLA Film and Television Archive, 18 Oct. 2004, https://web.archive.org/web/20041018220717/http://www.cinema.ucla.edu/tank/Gauges Horak.htm.

Huhtamo, Erkki. Illusions in Motion: Media Archaeology of the Moving Panorama and Related Spectacles. MIT Press, 2013. 
Johnson, Ted. "DOJ Will Review 70-Year-Old Consent Decrees That Regulate How Studios, Exhibitors Do Business." Variety, 2 Aug. 2018, https://variety.com/2018/politics/news/consent-decrees-department-of-justice-120289337 $\underline{4}$.

Johnson, Ted. "Will Studios Rush To Buy Theater Chains Without The Paramount Decrees? Don’t Bet On It.” Deadline, 19 Nov. 2019, https://deadline.com/2019/11/paramount-decrees-antitrust-makan-delrahim-1202789365/. Kalia, Ammar. "Ahead of Her Time': The Woman Who Recorded the News for 30 Years.” The Guardian, 4 Oct. 2019. www.theguardian.com, https://www.theguardian.com/film/2019/oct/04/giant-cookies-and-911-the-woman-who-r ecorded-the-news-24-hours-a-day.

Kattelle, Alan D. Home Movies: A History of the American Industry, 1897 - 1979. 1st edition, Transition Pub, 2000.

Madigan, Kevin "Netflix’s Alliance with the MPAA Signals a Shift in Platform Priorities.” Mister Copyright, http://mistercopyright.org/netflix-s-alliance-with-the-mpaa-signals-a-shift-in-platform-pri orities. Accessed 9 Dec. 2019.

Klinger, Barbara. Beyond the Multiplex : Cinema, New Technologies, and the Home. First edition, University of California Press, 2006.

Lakritz, Talia. “Parents Are Freaking out after 'Daniel Tiger's Neighborhood' Disappeared from 
Amazon Prime, and It Signals an Inevitable 'Streaming Bloodbath.'” Insider, https://www.insider.com/daniel-tigers-neighborhood-amazon-prime-2019-3. Accessed 9 Dec. 2019.

Lee, Edmund. "Netflix Will Keep 'Friends' Through Next Year in a \$100 Million Agreement." The New York Times, 4 Dec. 2018. NYTimes.com, https://www.nytimes.com/2018/12/04/business/media/netflix-friends.html.

Levy, Adam. "Look How Much Netflix Saves by Producing Its Own Originals." The Motley Fool, May 2018, https://www.fool.com/investing/2018/05/20/look-how-much-netflix-saves-by-producingits-own-o.aspx.

Lowe, Jim. The Videophile's Newsletter - Issue 01. Sept. 1976. Internet Archive, http://archive.org/details/videophile01.

Luckett, Moya. "Filming the Family": Home Movie Systems and the Domestication of Spectatorship. Feb. 1995, https://go.gale.com/ps/anonymous?id=GALE\%7CA90190304\&sid=googleScholar\&v=2. $\underline{1 \& i t=r \& \text { linkaccess }=\text { abs } \& i s s n=01491830 \& p=A O N E \& s w=w}$.

MacGillivray, Scott. Castle Films: A Hobbyist's Guide. iUniverse, Inc., 2004.

Marius, Michele. "On-Demand Streaming versus Traditional TV: Pros and Cons." ICT Pulse, 20 July 2018, https://www.ict-pulse.com/2018/07/on-demand-streaming-traditional-tv-pros-cons/.

McCarthy, Tyler. "Netflix Movies Disappearing 2015: Over 135 Movies And TV Shows 
Expiring In October.” International Business Times, 28 Sept. 2015, https://www.ibtimes.com/netflix-movies-disappearing-2015-over-135-movies-tv-shows-e xpiring-october-2117072.

McIntosh Stereopticon Company. Catalog of Stereopticons, Motion Picture Machines, Projection

Apparatus : Manufactured and Imported by the McIntosh Stereopticon Company.

Chicago, Ill., U.S.A. : 1915. Internet Archive, http://archive.org/details/gri catalogofste00mcin.

Moran, Robert. "Tale of the Tape: Why Film Fans Are Dropping Netflix for Physical Media." The Sydney Morning Herald, 15 Nov. 2019, https://www.smh.com.au/culture/movies/tale-of-the-tape-why-film-fans-are-dropping-net flix-for-physical-media-20191115-p53b1o.html.

Mutants. "Comparison of LaserDiscs With Other Formats.” Mr. Video Inc., 9 Dec. 2013, https://mistervideo.net/comparison-laserdiscs-formats/.

Nasaw, David. Going Out: The Rise and Fall of Public Amusements. Harvard University Press, 1999.

Nguyen, Kevin. “AT\&T's WarnerMedia Streaming Service to Cost 'between $\$ 16$ and $\$ 17$ a Month."” The Verge, June 2019, https://www.theverge.com/2019/6/6/18655637/att-warnermedia-streaming-service-pricefilm-tv-hbo-cinemax. 
Nordheimer, Jon. "U.S. and Industry Fight Piracy of Films.” The New York Times, 8 June 1975. NYTimes.com, https://www.nytimes.com/1975/06/08/archives/us-and-industry-fight-piracy-of-films.htm 1.

Novak, Matt. "How 1960s Film Pirates Sold Movies Before the FBI Came Knocking.” Paleofuture, https://paleofuture.gizmodo.com/how-1960s-film-pirates-sold-movies-before-the-fbi-cam e-1826287332. Accessed 9 Dec. 2019.

NYU - Dept. of Media, Culture, and Communication. Laserdisc. http://cultureandcommunication.org/deadmedia/index.php/Laserdisc. Accessed 9 Dec. 2019.

NYU - Dept. of Media, Culture, and Communication. Magic Lantern. http://cultureandcommunication.org/deadmedia/index.php/Magic Lantern. Accessed 9 Dec. 2019.

Otterson, Joe. “"The Simpsons' to Stream Exclusively on Disney+.” Variety, 12 Apr. 2019, https://variety.com/2019/tv/news/the-simpsons-streaming-disney-plus-1203187595/.

Pathescope Co. of America, Inc. Descriptive Catalogue of Pathescope De Luxe Special Features. New York, Pathescope Co. of America, Inc. Internet Archive, http://archive.org/details/descatal01path. Accessed 9 Dec. 2019.

Preservation Self-Assessment Program (PSAP) | Film. 
https://psap.library.illinois.edu/collection-id-guide/film\#film35mm. Accessed 9 Dec.

2019.

Preservation Self-Assessment Program (PSAP) | Record Protection Mechanisms.

https://psap.library.illinois.edu/collection-id-guide/recordprotection. Accessed 9 Dec. 2019.

Robinson, David. From Peep Show to Palace: The Birth of American Film. Columbia University Press, 1997.

Rogers, Ariel. On the Screen: Displaying the Moving Image, 1926-1942. Columbia University Press, 2019.

Schneider, Alexandra. "Time Travel with Pathé Baby: The Small-Gauge Film Collection as Historical Archive." Film History: An International Journal, vol. 19, no. 4, 2007, pp. $353-60$.

Schneider, Alexandra. "Time Travel with Pathé Baby: The Small-Gauge Film Collection as Historical Archive.” Film History: An International Journal, vol. 19, no. 4, 2007, pp. $353-60$.

Seitz, Matt Zoller. "Disney Is Quietly Placing Classic Fox Movies Into Its Vault, and That's Worrying." Vulture, Oct. 2019, https://www.vulture.com/2019/10/disney-is-quietly-placing-classic-fox-movies-into-its-v ault.html.

Shaw, Jessica Marmor, and Katie, Marriner. "Before You Sign up for Disney+, Use This 
Calculator to Add up the 'True' Cost of Your Streaming Services.” MarketWatch, https://www.marketwatch.com/story/before-you-sign-up-for-disney-this-calculator-addsup-the-true-cost-of-your-streaming-services-2019-11-13. Accessed 9 Dec. 2019.

Sherman, Alex, and Julia Boorstin. "NBC Finally Jumps in the Streaming Wars - Announces a New Service to Compete with Netflix, Disney and Amazon." CNBC, 14 Jan. 2019, https://www.cnbc.com/2019/01/14/nbc-to-launch-free-streaming-service-in-2020.html.

Sims, David. “A Streaming Service for Cinephiles.” The Atlantic, 17 Apr. 2019, https://www.theatlantic.com/entertainment/archive/2019/04/criterion-channel-streamingservice-launch $/ 587350 /$.

Singer, Ben. "Early Home Cinema and the Edison Home Projecting Kinetoscope." Film History, vol. 2, no. 1, 1988, pp. 37-69.

Steinberg, Brian, and Cynthia Littleton. "What We Know About NBCUniversal's Future Streaming Service.” Variety, Jan. 2019, https://variety.com/2019/tv/news/nbcuniversal-streaming-service-details-1203108034/.

The Kinetoscope.

http://www.loc.gov/static/collections/edison-company-motion-pictures-and-sound-record ings/articles-and-essays/history-of-edison-motion-pictures/origins-of-motion-pictures.ht ml. Accessed 9 Dec. 2019.

Theakston, Jack. "UNIVERSAL SHOW AT HOMES." Classic Horror Film Board, https://www.tapatalk.com/groups/monsterkidclassichorrorforum/universal-show-at-home 
s-t2220.html. Accessed 9 Dec. 2019.

THR. “'Song of the South,' 'Dumbo's' Jim Crow Scene Will Not Be on Disney+.” The Hollywood Reporter, https://www.hollywoodreporter.com/news/song-south-dumbos-jim-crow-scene-will-notbe-disney-1203624. Accessed 9 Dec. 2019.

Top Ten Reviews Contributor. “When Is DVD Ripping Illegal?” TopTenReviews, https://www.toptenreviews.com/when-is-dvd-ripping-illegal. Accessed 9 Dec. 2019.

Tuttle, Brad. "DVDs in the 'Disney Vault': B.S. Manipulative Marketing at Its Best (Worst?)." Time, 20 May 2011. business.time.com, http://business.time.com/2011/05/20/dvds-in-the-disney-vault-b-s-manipulative-marketin g-at-its-best-worst/.

“Video Tape Decay | VHS Tape Problems |." ScanCafe, https://www.scancafe.com/image-preservation/videotape-decay. Accessed 9 Dec. 2019.

Vile, John R. Bobbs-Merrill Co. v. Straus. https://www.mtsu.edu/first-amendment/article/250/bobbs-merrill-co-v-straus. Accessed 9 Dec. 2019.

Wasson, Haidee. "Electric Homes! Automatic Movies! Efficient Entertainment!: 16mm and Cinema's Domestication in the 1920s." Cinema Journal, vol. 48, no. 4, 2009, pp. 1-21. JSTOR.

Wells, Kentwood D. Magic Lanterns: Christmas Toys for Boys. no. 1, Spring 2010, p. 32. 
“What Is Blu-Ray?” Blu-Ray.Com, https://www.blu-ray.com/info/. Accessed 9 Dec. 2019.

"What's a DVD and How Does It Work?" Scientific American, https://www.scientificamerican.com/article/whats-a-dvd-and-how-does/. Accessed 9 Dec. 2019.

Wheeler, Jim, and Brothers, Peter. Videotape Preservation Fact Sheets. AMIA Preservation Committee, 2002 .https://amianet.org/wp-content/uploads/Resources-Video-Preservation-Fact-Sheets-2002 $\underline{-1 . p d f}$

Whitten, Sarah. "The Death of the DVD: Why Sales Dropped More than 86\% in 13 Years." $C N B C, 8$ Nov. 2019, https://www.cnbc.com/2019/11/08/the-death-of-the-dvd-why-sales-dropped-more-than- 8 6percent-in-13-years.html.

Willis, Karl D. “A Pre-History of Handheld Projector-Based Interaction.” Personal Ubiquitous Comput., vol. 16, no. 1, Jan. 2012, pp. 5-15. ACM Digital Library, doi:10.1007/s00779-011-0373-5.

Zoetrope History | Zoetrope \& Praxinoscope. http://www.zoetrope.org/zoetrope-history. Accessed 9 Dec. 2019. 